\title{
POLICIES AND BUSINESS STRATEGIES OF WOMEN ENTREPRENEURS: STUDY ON BEAUTY BUSINESS NADISSE SALON
}

\author{
Erna Maulina* dan Meci Nilam Sari** \\ * Department of Business Administration Science \\ Faculty Social and Political Science University of Padjadjaran \\ **Magister Student Bussines Administration \\ Faculty Social and Political Science University of Padjadjaran \\ Email:Erna.maulina@unpad.ac.id, Mecinilamsari@yahoo.co.id
}

\begin{abstract}
This paper contains about the implementation of business policy and strategy on beauty business Women Entrepreneur. The object studied is the salon NADISSE Bandung by discussing how the business strategy policy MSD salon NADISSE to be analyzed through internal environmental factors in the form of visible assets, invisible assets, and the capabilities of UMKM organizations. While external factors include the analysis of old competition, new competitors, replacement products, bargaining power of suppliers, and bargaining power of buyers in NADISSE salon SME business, and NADISSE Salon's competitive strategy includes promotion, product differentiation, and price leadership.
\end{abstract}

Keywords: Business policy and strategy, SMEs, women entrepreneurs

\section{KEBIJAKAN DAN STRATEGI BISNIS WANITA PENGUSAHA: STUDI PADA USAHA KECANTIKAN SALON NADISSE}

\begin{abstract}
ABSTRAK
Tulisan ini berisikan tentang penerapan tentang kebijakan dan strategi bisnis pada usaha kecantikan Women Entreprneur. Objek yang diteliti adalah salon NADISSE Bandung dengan membahas bagaimana kebijakan strategi bisnis UMKM salon NADISSE yang akan dianalisis melalui faktor lingkungan internal yang berupa aset terlihat, aset tidak terlihat, dan kapabilitas organisasi UMKM tersebut. Sedangkan faktor externalnya meliputi analisis pesaingan lama, pesaing baru, produk penganti, daya Tawar pemasok, dan daya tawar pembeli pada bisnis UMKM salon NADISSE, serta strategi bersaing Salon NADISSE meliputi promosi, diferensiasi produk, dan kepemimpinan harga.
\end{abstract}

Kata kunci: Kebijakan dan strategi bisnis, UMKM, wanita pengusaha 


\section{PENDAHULUAN}

Persaingan bisnis diberbagai sektor mulai bermunculan dari perusahaan bisnis yang besar sampai dengan usaha mikro kecil dan menengah atau yang biasa disebut dengan (UMKM). Kegiatan UMKM merupakan salah satu bidang usaha yang dapat berkembang dan konsisten dalam perekonomian nasional. UMKM merupakan usaha yang bersifat padat karya, tidak membutuhkan persyaratan tertentu seperti tingkat pendidikan, dan penggunaan modal usaha relatif sedikit serta teknologi yang digunakan cenderung sederhana.

UMKM turut berperan dalam meningkatkan perekonomian suatu negara. Menurut Hadinoto (2007), dengan meningkatnya usaha-usaha UMKM di Indonesia, diharapkan dapat meningkatkan kemampuan untuk menyerap tenaga kerja sekaligus mengurangi tingkat pengangguran serta kemiskinan yang ada di Indonesia. Artinya, dengan kemunculan UMKM dapat menciptakan lapangan pekerjaan bagi para masyarakat Indonesia dan juga turut menyumbang pendapatan pada negara Indonesia.

Kemajuan bisnis yang semakin pesat dapat dilihat dengan munculnya pelaku bisnis baru di sektor UMKM. Oleh karena itu para pelaku UMKM dapat menerapkan kebijakan strategi bisnis di sektor UMKM, gunanya adalah agar para pelaku UMKM dapat lebih unggul dan kompetitif dan bersaing untuk mencapai tujuan yang diharapkan dengan cara mempertahankan pelanggan lama dan merebut konsumen baru dengan keunggulan-keunggulan bersaing bisnis yang dimiliki oleh pelaku UMKM.

Menurut Undang-Undang Nomor 20 Tahun 2008 tentang Usaha Mikro, Kecil dan Menengah (UMKM), usaha kecil adalah usaha ekonomi produktif yang berdiri sendiri, yang dilakukan oleh orang perorangan atau badan usaha yang bukan merupakan anak perusahaan atau bukan cabang perusahaan yang dimiliki, dikuasai, atau menjadi bagian baik langsung maupun tidak langsung dari usaha menengah atau usaha besar dan kecil yang memenuhi kriteria.

Persaingan bisnis di sektor UMKM merupakan hal yang wajar di dunia bisnis, mengingat begitu banyaknya sektor UMKM di Indonesia sehingga menuntut para pelaku UMKM untuk jeli terhadap perubahan bisnis yang ada. Setiap UMKM berlomba menawarkan berbagai macam keunggulan dan manfaat produk yang dipasarkan, dengan tujuan untuk memperoleh keuntungan. Dalam menghadapi persaingan tersebut, UMKM harus cerdik dalam menciptakan ikatan tertentu antara produk yang ditawarkannya dengan konsumen. Perusahaan dituntut untuk dapat menentukan strategi bersaing bisnis yang tepat agar dapat bertahan dan memenangi persaingan, sehingga tujuan dari bisnis dapat tercapai dengan mendapatkan laba atau keuntungan yang dinginkan.

Usaha Mikro, Kecil dan Menengah (UMKM) diharapkan menjadi salah satu faktor penting dinegara Indonesia, dimana sektor UMKM adalah pendorong utama economic growth dinegara Indonesia. Hal tersebut dikarenakan keberadaan UMKM telah banyak menyediakan entrepreneurial resources dan employment opportunities bagi masyarakat. Oleh karena itu pelaku bisnis UMKM Indonesia harus terus memperbaiki diri dengan menciptakan daya saing yang global maupun international agar tetap mempertahankan exsistensinya didunia bisnis.

Peminat orang-orang untuk melakukan bisnis di sektor UMKM mengalami kemajuan yang cukup signifikan. Menurut data IWAPI (Ikatan wanita pengusaha Indonesia) 50\% bisnis yang ada di Indonesia adalah UMKM sedangkan $60 \%$ bisnis UMKM di Indonesia yang menjadi pelaku usahanya adalah wanita pengusaha atau women entrepreneur. Jadi secara garis besar dapat kita lihat bagaimana UMKM dapat memajukan perekonomian Indonesia untuk lebih baik lagi

Pada era teknologi yang semakin maju dan tuntutan perekonomian yang semakin tinggi 
membuat wanita pengusaha atau women entreprneur membuka bisnis di sektor UMKM gunanya adalah untuk mempertahankan kehidupan mereka lebih baik lagi baik secara finansial ataupun non finansial. Oleh karena itu Semua bidang bisnis sudah terbuka bagi wanita pengusaha. Wanita bukan lagi sebagai ibu rumah tangga, pekerja kantoran, dan pelajar/mahasiswi, tetapi sekarang dengan perubahan zaman, wanita bisa menjadi women entrepreneur.

Motivasi wanita untuk membuka bisnis karena ingin berprestasi dengan memanfaatkan bakat dan keterampilan yang ada pada dirinya. Selain itu dengan membuka usaha, wanita dapat menjaga eksistensinya di lingkungan sekarang ini, dimana Status sebagai pemilik perusahaan tentunya akan memberi kebanggaan tersendiri yang tidak dirasakan, jika dia bekerja dengan orang lain sebagai karyawan.

Wanita pengusaha Indonesia rata-rata memilih bisnis sesuai dengan bakat dan keterampilan yang mereka punya. Seperti contohnya owner salon NADISSE yang memilih salon kecantikan dan perawatan tubuh sebagai peluang bisnis serta memanfaatkan bakat dan keterampilan yang ada. NADISSE salon sudah berdiri dari 5 tahun yang lalu dijakarta dan akhirnya memberanikan diri untuk mengembangkan bisnisnya dengan membuka cabang di Patiukur 51 Bandung.

Perkembangan salon kecantikan memang semakin meningkat. Hal ini juga akan membawa pengaruh positif terhadap pesaingan pelaku bisnis dibidang salon kecantikan. Tingginya permintaan pasar dan munculnya beragam UMKM salon maupun SPA memaksa para pengusaha di dunia kecantikan untuk menawarkan jasa yang lebih baik dan beragam sehingga dapat menarik pelanggan.

NADISSE salon memiliki konsep strategi bisnis yang unik yaitu setiap tempat salonnya mempunyai tema dekorasi yang berbeda dan unik dari pada salon-salon yang lain. Misalnya saja di Jakarta rata-rata salon ini mengusung tema Princes atau Barbie. Sedangkan di
Bandung NADISSE salon mengusung tema GOGreen yaitu dengan unsur pemanfaatan karung bekas dan tanaman hijau. Oleh karena itu hal inilah yang menjadi perhatian peneliti untuk mengkaji dan membahas lebih lanjut tentang kebijakan strategi bisnis NADISSE salon. Apakah pelaku usahanya bisa terus bertahan dengan pesaingan yang semakin ketat didunia bisnis kecantikan. Karena mengingat begitu banyaknya UMKM yang bergerak dibisnis kecantikan. Dimana rata-rata inovasi, kreativitas, dan pengembangan produk merupakan hal yang sering ditiru atau di modifikasi oleh para pelaku UMKM kecantikan lainnya. Oleh karena itu dalam penelitian bisnis kecantikan NADISSE salon, Peneliti memfokuskan pada masalah kebijakan strategi bisnis yang ada agar NADISSE salon tetap bisa mempunyai keunggulan untuk bersaing secara kompetitif.

\section{METODE PENELITIAN}

Metode penelitian ini, peneliti menggunakan pendekatan kualitatif yang bersifat Deskriptif yaitu untuk mengetahui atau menggambarkan kenyataan dari kejadian yang diteliti serta memanfaatkan sumber-sumber pustaka yang relevan sesuai dengan kajian peneliti.

Pengumpulan data pada studi kebijakan strategi bisnis kecantikan women entrepreneurship dilakukan dengan wawancara mendalam terhadap informan terkait secara langsung dengan owner/pemilik usaha dan karyawan NADISSE salon. Serta Pengumpulan data juga dilakukan dengan cara observasi dan analisi dokumentasi serta langsung kelapangan yang berlokasi di jln. Patiukur No 51 Bandung. Observasi dilakukan untuk meninjau bagaimana kebijakan strategi bisnis kecantikan women entrepreneurship NADISSE salon.

Data yang disajikan pada artikel ini akan di analisis dengan menggunakan analisis kebijakan strategi bisnis lingkungan internal dan lingkungan external five forces module Michael 
Porter sedangkan analisis strategi bersaing bisnis mengunakan 3 strategi generik Michael Porter.

\section{HASIL DAN PEMBAHASAN}

Persaingan UMKM yang semakin ketat membuat para pelaku bisnis UMKM untuk selalu meningkatkan daya saing bisnisnya, gunanya adalah agar UMKM di Indonesia bisa tetap bertahan di dunia bisnis. Salah satu cara yang dapat dilakukan oleh para UMKM adalah dengan memanfaatkan kelebihan yang ada dan meminimalisir kekurangan yang dimiliki oleh pelaku UMKM. Untuk itu, UMKM harus merencanakan kebijakan strategi bisnis yang tepat agar mampu unggul dan bersaing secara kompetitif.

Dalam penelitian ini, peneliti menggunakan Salon NADISSE sebagai objek penelitian. Salon Nadisse merupakan salon kecantikan bagi para wanita khususnya dan salon ini sudah berdiri sejak 5tahun belakangan ini tetapi untuk wilayah Bandung baru berdiri kurang lebih 1 tahun. Salon NADISSE berada di jalan Patiukur no 51 Bandung buka dari jam 10.00 sampai jam 19.00. Nadisse salon menawarkan banyak produk kecantikan untuk tubuh dan wajah. Seperti potong rambut, blow, catok, bonding, clouring, lulur, facel, dan lain-lain dan tidak lupa NADISSE juga menawarkan kosmetik bagi para wanita pencinta barang Korea, Thailand dan Jepang. Dimana pada zaman sekarang rata-rata di negara-negara berkembang Konsumen wanita lebih tertarik dengan produk kencatikan yang berasal dari negara seperti Korea, Thailand dan jepang.

NADISSE salon merupakan jenis sektor usaha kecil. Secara khusus NADISSE salon tidak merincikan Visi dan Misi tetapi dapat memberikan mutu dan pelayanan terbaik dengan harga yang terjangkau bagi pelangganya kaum wanita. Dengan menjaga kualitas dan pelayanan maka secara tidak langsung pelanggan akan merasa puas dengan produk yang ditawarkan sehingga pelanggan dan konsumen akan kembali datang ke NADISSE salon.
NADISSE salon memiliki 6 orang karyawan, rata-rata para karyawan disalon NADISSE adalah tamatan SMA yang mengambil jurusan kecantikan. Oleh karena itulah dari segi sumber daya manusia NADISSE cukup unggul karena benar-benar memilih SDM yang kompeten dibidangnya. Sedangkan dari sumber daya alam NADISSE mengolah produknya sendiri secara alami inilah yang membedakan salon NADISSE denga salon yang lain.

\section{Analisis Faktor Internal}

Faktor lingkungan internal adalah salah satu hal yang perlu dibahas, dengan menganalisis faktor lingkungan internal maka perusahaan akan tau sejauh mana bisnisnya diminati oleh pasar dan sejauhmana keefektifan pelaku bisnis dalam mengola bisnis secara baik sehingga bisa tetap selalu unggul di sektor UMKM. Dengan mengidentifikasi lingkungan internal pada bisnis UMKM maka kita akan mengetahui profil dan keunggulan strategi bisnis yang di miliki, serta kelemahan dan batasan-batasan yang ada dalam UMKM. Kegunaan dalam menganalisis lingkungan internal bagi pelaku bisnis adalah mempermudahkan untuk meninjau kembali apaapa yang nanti menjadi kendala didalam usaha bisnis yang dijalani. Oleh karena itu Lingkungan internal perlu dianalisis untuk mengetahui kekuatan (strength) dan kelemahan (weaknesses) yang ada dalam perusahaan.

Menurut Hubeis dan Najib (2014) lingkungan kini mengalami perubahan yang luar biasa dan intensitasnya kini semakin sering serta sukar sekali diramalkan. Akibatnya, persaingan menjadi semakin sengit dan permasalah yang dihadapi juga semakin hari menjadi semakin rumit. Untuk itu, sebelum berbagai proses lain dalam manajemen strategik dilakukan, maka analisis lingkungan bisnis yang merupakan hal yang pertama untuk dilakukan. Yang dimaksud dengan analisis adalah penelusuran kondisi eksternal dan internal yang dihadapi perusahaan sampai pada pangkalnya. Dengan demikian perusahaan akan dapat mewaspadai dan 
memahami implikasi-implikasi perubahan untuk kemudian dapat bersaing secara lebih efektif.

Pada penelitian ini, peneliti dapat menganalisis tentang lingkungan internal pada NADISSE salon. lingkungan internal yang peneliti temukan adalah beberapa kekuatan yang dimiliki oleh Salon NADISSE, antara lain yaitu selalu memberikan pelayanan yang terbaik dan menjaga untuk selalu up to date baik dalam alatalat dan produk-produk yang digunakan maupun pengetahuan tentang trend kecantikan yang berubah tahun maka semakin berubah juga trend kecantikan yang ada. Berikut adalah skema tentang proses pelayanan salon NADISSE

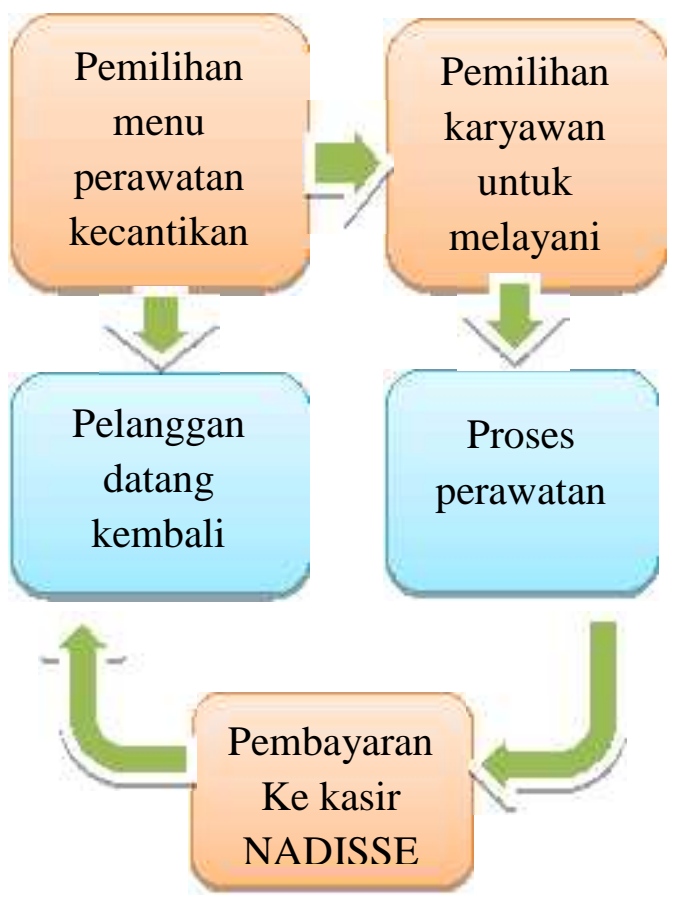

Skema proses NADISSE salon

Secara fundamental NADISSE salon memiliki lingkungan internal yang bagus, kreatif, inovasi, dan mempunyai semangat yang tinggi dalam memasarkan produknya. Salah satu dari sumber daya yang khas pada NADISSE salon adalah berupa aset telihat, aset tidak terlihat dan kapabilitas organisasi yang nantinya merupakan salah satu kelebihan dalam UMKM salon NADISSE, maka ini merupakan salah satu faktor internal yang dapat membuat salon ini untuk terus maju dari pada pesaing-pesaing bisnis kecantikan yang ada.
Aset terlihat NADISSE salon adalah Tempat yang unik yang di kreasikan dengan mengusung tema Go Green sehingga pengunjung ditawarkan pemandangan yang sejuk dan alami. Dekorasi pada NADISSE salon terbuat dari karung bekas dan setiap pojok diberikan bunga hidup untuk menambah kesan alami ruangan. Oleh karena itulah ini merupakan salah satu kelebihan dari NADISSE salon dari pada salon-salon yang lainnya. Aset terlihat lainnya adalah dari segi produk yang ditawarkan oleh NADISSE salon yaitu mereka mengunakan pencucian dan perawatan hairclip yang ramah lingkungan. NADISSE salon juga menawarkan produk kecantikan yang terbuat dari bahan-bahan yang alami sehingga aman untuk dipakai oleh pelanggan. Dan terakhir NADISSE juga menjual alat-alat kosmetik yang terjangkau oleh para pelangganya.

Aset tidak terlihat pada NADISSE salon adalah yaitu dari reputasi atau branding dari UMKMnya tersendiri. Kennedy (1977) menyatakan bahwa image memiliki kesamaan dengan reputasi karena perusahaan pun membutuhkan waktu yang lama untuk membentuk sebuah image. Sehingga perdebatan mengenai definisi image dan reputasi tidak diperlukan, selama publik dapat memahami konteks dalam memahami kedua konsep tersebut.

NADISSE SALON merupakan UMKM yang bergerak pada bisnis salon dan kecantikan dan Baru beberapa bulan saja orang-orang di sekitar Patiukur Bandung dan daerah lainnya tau dengan NADISSE salon karena pemakaian promosi yang baik sehingga dapat menunjang brand dari UMKM tersebut. Selanjutnya reputasi UMKM didapat dari pelayanan dan rasa tangung jawab sosialnya kepada para pelanggan dengan pelayanan yang baik dan cekatan mampu meningkatkan reputasi bagi usaha NADISSE salon. Bahan-bahan kecantikan yang alami membuat pelanggan dan kosumen percaya akan salon kecantikan ini. Dan hal inilah yang membuat NADISSE salon mempunyai aset tak 
terlihat yang cukup bergensi dan bagus dari pada salon-salon lainnya.

Kapabilitas organisasi NADISSE salon tidak luput dari perhatian kita. Dimana kapabilitas organisasi salon ini terlihat dari keterampilan SDM dalam melayani pelanggan. Walaupun usaha ini masih tergolong kecil dan cukup baru tapi NADISSE salon mampu mempekerjakan karyawannya sebanyak 6 orang karena faktor pengunjung yang banyak setiap harinya.

Hasil analisis lingkungan internal, juga ditemukan beberapa kelemahan yang dimiliki oleh Salon NADISSE. Salah satu kelemahan Salon NADISSE yaitu tempatnya yang kecil karena masih dalam kondisi sewa jadi para pelanggan saat waktu menunggu kurang begitu nyaman karena kondisi ruang tunggu yang begitu sempit. Alat-alat untuk menunjang keefektifan salon masih belum lengkap seperti kursi untuk menunggu, peralatan kecantikan dan lain-lain, mengingat tempat dan juga karena masih baru dibuka didaerah dipatiukur 51 Bandung.

\section{Analisis Faktor External}

Lingkungan eksternal adalah lingkungan yang berada di luar organisasi dan perlu dianalisis untuk menentukan kesempatan (opportunities) dan ancaman (threath) yang akan dihadapi UMKM, karena mengingat UMKM sangat sering sekali menjadi bahan contoh untuk orang-orang memulai bisnis baru. UMKM harus menganalisis faktor-faktor external apa saja yang menjadi ancaman dan kesempatan bagi mereka untuk bisa berkembang dan bertahan di dunia bisnis. Terdapat dua perspektif untuk mengkonseptualisasikan lingkungan eksternal. Heizer dan Render dalam Kuncoro, (2006) menyatakan faktor-faktor yang berpengaruh terhadap lingkungan eksternal adalah kondisi perekonomian, budaya, demografi, dan peraturan pemerintah. Lain halnya dengan Bourgeois (dalam Kuncoro, 2006) yang mengatakan bahwa lingkungan eksternal dipengaruhi oleh konsumen, pesaing, pemasok dan peraturan pemerintah.
Menurut Porter Porter's Five-Forces mengatakan bahawa Model analisis lingkungan external ini merupakan salah satu pendekatan yang digunakan secara luas untuk mengembangkan kebijakan strategi bisnis pada sebuah perusahaan termasuk kedalamnya adalah UMKM. Model pendekatan Porter yaitu persaingan antar perusahaan saingan, potensi masuknya pesaing baru, potensi pengembangan produk-produk pengganti, daya tawar pemasok, dan daya tawar konsumen (David, 2012).

\section{Persaingan Antar UMKM}

Analisis faktor external yang pertama adalah pesaingan antar perusahaan saingan. Ini merupakan salah satu faktor penting yang harus dilihat oleh salon NADISSE mengingat salon ini baru berada didaerah Bandung jadi mereka harus meindentifikasi siapa saja Persaing lama yang ada. Ancaman yang dimiliki Salon NADISSE salah satunya yaitu persaingan yang begitu ketat. Banyaknya salon sejenis yang ada dalam industri salon ini membuat Salon NADISSE harus berusaha lebih baik lagi agar dapat bersaing. Oleh karena itulah Salon NADISSE harus memberikan yang terbaik dari segi pelayanan, produk-produk, harga yang murah. Sehingga pelanggan tetap terjaga dan tidak berpaling kepada salon yang lain. Keuntungan yang ada pada salon NADISSE ini dari sisi tempatnya yaitu didaerah Patiukur tidak ada salon sejenis seperti NADISSE dimana rata-rata patiukur banyaknya kuliner dan lain-lain.

Intensitas persaingan antar perusahaan saingan cenderung meningkat ketika jumlah pesaing bertambah, ketika pesaing lebih setara dalam hal ukuran dan kapabilitas, ketika permintaan akan produk menurun, dan ketika potongan harga menjadi hal yang umum. Oleh karena itulah analisis faktor external sangat diperlukan mengingat banyak sekali UMKM salon dikota bandung baik pesaing lama.

\section{Potensi Pesaingan Baru}

Ancaman pesaingan baru ini merupakan salah satu faktor yang perlu diinditifikasi karena 
pesaing baru ini biasanya mempunyai strategi yang cukup baik dari segi promosi dan pelayanannya mengingat biasanya pesaing baru mengadakan diskon besar-besaran untuk mengaet pelanggan lebih banyak lagi untuk bisa mengenal UMKM atau pesaing baru tersebut. Oleh karena itu NADISSE harus mempunyai cara-cara unik agar pelannggan tidak berpaling yaitu dengan promosi atau strategi bersaingan bisnis yang bagus ataupun dengan cara harga yang rendah tapi kualitas produk yang ditawarkan tetap alami dan bagus sehinga pangsa pasar atau pelanggan yang dimiliki oleh NADISSE salon tidak akan lari kepada para pesaing baru yang merintis usahanya dibidang salon.

\section{Potensi Pengembangan Produk-Produk Pengganti}

Pengembangan produk penganti pastinya menjadi ancaman bagi NADISSE salon. Karena dengan adanya produk penganti terkadang konsumen belum tentu percaya dengan produk yang ditawarkan oleh karena itu produk penganti ini bisa dijadikan peluang oleh NADISSE salon dengan cara menawarkan cara kerja produk yang bagus serta pemberian testimoni yang baik juga kepada pelanggan. Sehingga para pelanggan tidak takut akan adanya produk pengganti dan ini bisa jadi menjadi poin positif bagi NADISSE.

Ancaman dari produk pengganti tersebut sebenarnya merupakan produk yang dipakai di salon yang dijual bebas di pasar. Salon NADISSE harus dapat terus meyakinkan pelanggan bahwa hasil yang maksimal dari perawatan rambut dan tubuh maupun kosmetik yang dijualnya sebagai produk pengganti yang baik juga bagi pelanggan. Jika Salon NADISSE tidak dapat meyakinkan hal tersebut ke pelanggan, pelanggan akan beralih ke produk pengganti yang lain yang mereka anngap aman bagi perawatn tubuh mereka.

Besarnya sebuah tekanan kompetitif yang berasal dari pengembangan produk pengganti biasanya ditunjukkan oleh rencana pesaing untuk mengembangkan kapasitas produksi, selain tingkat penjualan dan laba. Tekanan kompetitif dari produk pengganti bertambah, ketika harga produk pengganti menurun dan ketika biaya peralihan konsumen menurun. Kekuatan kompetitif produk pengganti dapat diukur lewat penelitian terhadap pangsa pasar yang berhasil dari produk tersebut

\section{Daya Tawar Pemasok}

Daya tawar pemasok mempengaruhi tingkat persaingan dalam sebuah industri, khususnya ketika terdapat banyak pemasok, ketika terdapat sedikit bahan mentah pengganti yang bagus, atau ketika biaya peralihan ke bahan mentah lain sangat tinggi. Pemasok atau penjual dapat menggunakan kekuatan tawar-menawar terhadap pembeli dalam industri dengan cara menaikkan harga atau menurunkan kualitas produk atau jasa yang dibeli. Kondisi-kondisi yang membuat posisi pemasok kuat cenderung menyerupai kondisi yang membuat pembeli kuat.

Daya tawar pemasok yang tidak terlalu tinggi membuat NADISSE salon dapat bernafas lega tentang harga yang ditawarkan oleh pemasok tersebut. mengetahui bahwa pemasoknya tidak akan seenaknya menaikkan harga. Namun, Salon NADISSE juga harus tetap menjaga hubungan baik dengan pemasok agar dapat mempertahankan daya tawar pemasok yang tidak terlalu tinggi.

\section{Daya Tawar Konsumen}

Daya tawar konsumen ini merupakan salah satu hal perlu diperhatikan pada faktor external UMKM NADISSE salon, karena apabila pelanggan datang kesalon NADISSE dengan melakukan sejumlah perawatan yang cukup banyak dari pada pelanggannya yang lain maka NADISSE harus dapat menawarkan hal yang lebih juga kepada konsumen misalnya dengan pemberian produk gratis sehingga pelanggan akan merasa puas dan senang untuk melakukan perawatan di NADISSE salon.

Dari fakta yang peneliti dapatkan bahwa NADISSE salon telah melakukan usaha 
semaksimal mungkin terhadap daya tawar konsumen yang ada. dan terbukti yaitu salon ini tetap ramai sampai malamdan tidak pernah sepi pengunjung. Dengan adanya daya tawar dari konsumen maka ini menjadi kekuatan yang cukup besar dalam persaingan ketika konsumen membeli dalam jumlah besar. UMKM salon pesaing bisa saja menawarkan layanan khusus untuk mendapatkan loyalitas konsumen pada saat daya tawar konsumen kuat. Daya tawar konsumen juga akan lebih tinggi ketika produk yang dibeli merupakan produk yang standar atau tidak terdiferensiasi.

Oleh karena itu dengan mempertimbangkan daya tawar konsumen sebagai salah salah satu peluang dari NADISSE salon maka hal ini bisa membuat usaha NADISSE salon tetap terjaga dan bertahan di dunia bisnis kecantikan sehinga salon NADISSE tetap menjaga keunggulanya dan bersaing secara kompetitif.

\section{Analisis Strategi Bersaing Bisnis}

Mencapai suatu strategi yang tepat maka harus dibutuhkan suatu manajemen strategi bersaing bisnis yang bagus. Banyak cara yang dilakukan oleh UMKM dalam mempertahankan eksistensinya. UMKM merupakan salah satu usaha yang sangat mendukung perekonomian dinegara berkembang apalagi saat adanya krisis perekonomian. Didalam UMKM harus mempunyai analisis strategi bersaing bisnis yang bagus agar nantinya para pesaing bisnis yang lama dan baru tidak dapat menjatuhkan bisnis yang telah kita rintis sebelumnya. Kebijakan strategi bersaing bisnis merupakan hal yang menjadi faktor utama dalam menarik pelanggan dan konsumen karena apabila kita mempunyai strategi bisnis yang baik dan sangat menguntungkan bagi para pelanggan dan konsumen maka ini merupakan peluang yang baik bagi UMKM.

NADISSE salon adalah salah satu salon yang baru berada di Bandung tetapi strategi bersaing bisnis yang ada pada salon ini tidak kalah baiknya dengan salon-salon yang ada. Strategi bersaing Bisnis pada NADISSE salon adalah dengan cara promosi yang baik, diferensiasi produk yang berkualitas, harga yang murah.

\section{Strategi Promosi}

Strategi promosi merupakan hal yang paling penting bagi usaha UMKM karena dengan adanya promosi maka konsumen akan tau apa yang ditawarkan oleh UMKM tersebut kepada konsumen. Strategi promosi yang dilakukan oleh NADISSE salon adalah dengan cara yang unik dan kreatif yaitu dengan mengunakan media sosial untuk mempromosikan produknya. Karena sangat jarang sekali kita lihat salon-salon yang berbasis UMKM memanfatkan teknologi dan media sosial sebagai sarana promosinya. NADISSE melakukan promosi lewat Instagram, dengan Instagram inilah NADISSE bisa juga menjual produk kosmetik atau perawatan tubuh lainnya.

NADISSE salon melakukan promosi dengan pembagian brosur dan kupon-kupon gratis melalui pasar Gazibu yang ada di Bandung. Setiap minggu NADISSE menawarkan kupon gratis dan diselipkan brosur tentang salon NADISSE. Biasanya pembelian sekitar 40rb mendapatkan kupon gratis dengan potongan harga $10 \%$ di salon NADISSE. Selain itu setiap pelanggan atau konsumen yang telah berkunjung disalon NADISSE juga diberikan kartu identitas dan apabila telah terkumpul 10 stempel NADISSE maka akan gratis $1 \mathrm{x}$ perawatan tubuh di NADISSE salon. Hal ini lah yang menjadi keunggulan dalam strategi bisnis NADISSE salon untuk bisa bertahan di dunia bisnis UMKM salon.

Strategi promosi yang dilakukan oleh salon NADISSE sudah cukup bagus bagi UMKM yang baru melakukan bisnisnya diwilayah Bandung. Target pasar dari salon NADISSE ini adalah ibu-ibu dan mahasiswi disekitar wilayah salon yang ada. oleh karena itulah NADISSE salon dapat memanfaatkan strategi promosi dengan baik terhadap para pelangganya. Dengan adanya promosi melalui media sosial, brosur, mulut ke mulut, kupon gratis, kupon identitas. 
Dan lain-lainya maka hal inilah yang nantinya akan menunjang pendapatan atau keuntungan dari NADISSE salon.

\section{Diferensiasi Produk}

Memasarkan produk di tengah persaingan pasar yang kian tinggi, tentu bukan perkara mudah bagi sebagian besar pelaku usaha. Dibutuhkan strategi bersaing bisnis yang tepat, agar produk yang ditawarkannya tidak tenggelam di tengah persaingan pasar yang cukup tajam. NADISSE salon mecoba untuk menawarkan diferensiasi produk kepada para konsumenya, dimana diferensiasi produk inilah yang tujuanya untuk membedakan antara salon yang lain sehinga konsumenpun juga merasa puas dan menemukan produk yang sesuai juga nantinya untuk mereka pakai.

Diferensiasi bisa dilakukan dengan menciptakan produk yang berbeda, NADISSE salon sudah melakukan hal itu, salon ini sudah menciptakan produk yang berbeda dengan bahan yang alami baik itu untuk rambut atau untuk wajah seperti hairmask dan facel agar tubuh dari para pelanggan tetap mendapatkan garansi yang aman disalon NADISSE karena produk yang dibuat secara lamai inilah. Setelah itu NADISSE salon juga memberikan pelayanan yang berbeda, atau menciptakan image produk yang unik dan berbeda dari pesaing lainnya. Dengan memberikan diferensiasi produk kepada para konsumen maka dengan mudah produk ini dapat dikenali dan memberikan daya tarik tersendiri bagi para konsumen.

Mc Carty dan Perreault mendefinisikan diferensiasi produk adalah penawaran produk perusahaan yang lebih baru, lebih cepat dan lebih murah yang akan menciptakan nilai yang lebih tinggi bagi pelanggan produk pesaing (A.W. Tunggal, 2001: 37) Selanjutnya dijelaskan oleh (Kotler 2002: 329: 332) bahwa banyak produk dapat didiferensiasi berdasarkan bentuk, ukuran, model atau struktur fisik sebuah produk.
Hal lain yang dilakukan oleh NADISSE salon dalam diferinsasi produk adalah selain produknya yang alami mereka juga mengemas produk yang dibeli oleh konsumen dengan paper bag kecil agar bahan dalam produk tersebut tetap terjaga dan awet. Sedangkan untuk kosmetik tetap memakai plastik yang ramah lingkungan yang dapat hancur dalam beberapa hari. Oleh karena itulah selain tempatnya yang ramah lingkungan dan proses perawatan yang ramah lingkungan mereka juga memanfaatkan pembungkusan produk yang ramah lingkungan sehingga totalitas dari salon NADISSE ini tinggi terhadap lingkungan yang ada khususnya kota Bandung.

\section{Cost leadership}

Cost leadership adalah salah satu strategi bersaing bisnis yang paling susah untuk diterapkan karena mengingat biaya produksi dan biaya operasional lainnya apakah sepadan dengan harga yang ditawarkan kepada konsumen. Kepemimpinan bersaing dnegan harga yang rendah merupakan hal yang paling menguntungkan oleh para konsumen apalagi dengan harapan kualitas dan kuantitas yang baik dan bagus juga sehinga konsumen atau pelanggan akan mencari atau membeli produk kita kembali dna berdampak juga kepada peningkatan profit perusahaan.

NADISSE salon adalah salah satu salon yang berada di patiukur Bandung yang memliki strategi bersaing bisnis dengan harga yang rendah. Hal ini dilakukan untuk menyenangkan hati para pelangganya agar dapat berkunjung kembali kesalon. NADISSE salon melakukan paket hemat perawatan yaitu hairmask, facel, dan dry hanya 25ribu dan paket creambath, dry, hairwash 25ribu juga, tetapi seperti salon MEMORI atau salon pesaing yang lama menetapkan tarif atau harga untuk creambath saja 30rb. Kenapa NADISSE salon dapat bersaing dengan harga yang rendah karena mereka melakukan bahan alami yang dioleh dengan produk yang berkualitas juga sehingga dengan kepemimpinan harga yang murah ini 
dapat menguntungkan bagi pelangganya apalagi target pasarnya adalah mahasiswi.

Oleh karena itulah dengan kepemimpinan harga adalah salah satu strategi bersaing bisnis yang sulit sebenarnya diterapkan karena mnegingat faktor-faktor pengikat lainnya terhadap usaha UMKM tapi disalon NADISSE dengan kepemimpinan harga membuat mereka bisa tetap bertahan dan mampu bersaing terhadap pesaing lama yang ada.

\section{SIMPULAN}

Berdasarkan hasil penelitian, maka Peneliti dapat mengambil kesimpulan sebagai jawaban dari rumusan masalah yang menjadi acuan penelitian, maka dapat disimpulkan bahwa kebijakan strategi bisnis NADISSE salon pada faktor lingkungan internal dan lingkungan external serta faktor analisis strategi bersaing bisnis sejauh ini sudah bagus dan mampu mempunyai daya saing tinggi. Dilihat dari segi promosi yang baik, diferensiasi produk yang berkualitas, dan juga kepemimpinan harga yang murah dari pada salon-salon kecantikan lainnya yang berada disekitaran Patiukur dan Dago Bandung.

\section{DAFTAR PUSTAKA}

Amin Widjaya Tunggal. 2001. Memahami Konsep Economic Value Added (EVA) dan Value Based Management (VBM). Harvarindo

David, Fred R. 2012. Strategic Management Concept and Cases (c) Pearson Prentice Hall. USA

Hadinoto, Soetanto. 2007. Micro Credit Challenge: Cara Efektif Mengatasi Pengangguran dan Kemiskinan di Indonesia, Jakarta, Elex Media Komputindo.

Hubeis dan Najib. 2014. Manajemen strategik dalam pengembangan daya saing organisasi, Jakarta PT. Elex Media Komputindo.

Kennedy, XJ, (1997) An introduction to fiction. Canada: little, Brwon and company. Boston toroton.
Kotler, Philip \& Amstrong, Gary (2002). Dasardasar pemasaran. Jakarta: Prenhallindo.

Mudrajad Kuncoro, 2006, Ekonomi Pembangunan, Teori, masalah dan kebijakan, Cetakan pertama, Unit penerbitan dan percetakan akademi manajemen perusahaan YKPN, Yogyakarta.

Porter, M. E. (1976). "How Competitive Forces Shape Strategy", Harvard Business Review, Vol.57, No.2, pp.142- 167. (1993). Keunggulan Bersaing. Alih Bahasa Agus Dharma dan Agus Maulana. Jakarta: PT Gelora Aksara Pratama

UU Republik Indonesia nomor 20 tahun 2008 tentang Usaha Mikro Kecil dan Menengah. Retrieved September, 13, 2014 from http://bumn.go.id/data/ uploads/files/1/20.pdf www.iwapi.id 